\title{
Diversidade bacteriana associada à biodegradação de resíduos sólidos urbanos
}

\author{
Bacterial diversity associated with biodegradation of urban solid waste

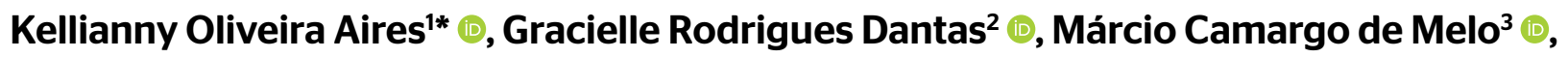 \\ Rui de Oliveira4 ${ }^{\mathbb{D}}$, Veruschka Escarião Dessoles Monteiro ${ }^{3}$ (1)
}

口-

\section{RESUMO}

O conhecimento das populações bacterianas responsáveis pela biodegradação dos resíduos sólidos dispostos em aterros sanitários pode levar ao desenvolvimento de alternativas tecnológicas viáveis para o tratamento e a estabilização dos resíduos, resultando em impactos positivos para a operação de aterros, a recuperação de energia, a saúde pública e o meio ambiente. O objetivo deste trabalho foi caracterizar a diversidade bacteriana associada à biodegradação de resíduos sólidos urbanos (RSU) aterrados em uma célula experimental no município de Campina Grande, Paraíba. O estudo abrangeu as etapas de construção, planejamento estatístico dos bairros de Campina Grande para coleta e preenchimento da célula experimental com RSU. As amostras de DNA das bactérias encontradas nos RSU foram extraídas com o Kit Power Soil DNA Isolation. Em seguida, foi realizada a análise genética com primers universais para bactérias via reação em cadeia da polimerase (PCR) e eletroforese em gel de gradiente com desnaturante (DGGE), e, por fim, sequenciamento genético (região $16 S$ do RNAr). Após o exame microbiológico, as principais bactérias associadas aos táxons foram: Uncultured Pseudomonas sp. Uncultured bacterium, Enterobacter sp., Klebsiella pneumoniae e Uncultured Bacillus $s p$., sugerindo que nos RSU existem representantes ainda desconhecidos e/ou não isolados que estão relacionados aos processos de hidrólise, acidogênese e acetogênese na digestão anaeróbia dos resíduos.

Palavras-chave: resíduos sólidos urbanos; biodegradação; bactérias.

\begin{abstract}
The knowledge of bacterial populations responsible for the biodegradation of solid waste disposed of in landfills can lead to the development of feasible technological alternatives for the treatment and stabilization of residues, resulting in positive impacts for the operation of landfills, energy recovery, public health and the environment. The objective of this work is to characterize the bacterial diversity associated to the biodegradation of grounded MSW in an experimental Cell in the city of Campina Grande-PB. The study covered the stages of construction, statistical planning of the districts of Campina Grande-PB for collection and filling of the experimental Cell with MSW. The DNA samples of the bacteria found in the MSW were extracted with the Power Soil DNA Isolation Kit, then the genetic analysis was performed with universal primers for bacteria via PCR and DGGE, and finally, genetic sequencing (16S RNA region). Following the microbiological examination, the main bacteria associated to the taxons were: Uncultured Pseudomonas sp. Uncultured bacterium, Enterobacter sp., Klebsiella pneumoniae, Uncultured Bacillus sp., suggesting that in the MSW there are still unknown and/or non-isolated representatives that are related to hydrolysis, acidogenesis and acetogenesis in the anaerobic digestion of the residues.
\end{abstract}

Keywords: municipal solid waste; biodegradation; bacteria.

\section{INTRODUÇÃO}

No processo de biodegradação dos resíduos sólidos urbanos (RSU), a matéria orgânica é convertida por meio de uma cooperação entre diferentes grupos microbianos de estirpes facultativas e anaeróbias estritas (SZYŁAK-SZYDŁOWSKI; KORNIŁŁOWICZ-KOWALSKA, 2012). Assim, as transformações da matéria orgânica complexa em produtos mais simples podem ocorrer em ambientes aeróbios e anaeróbios.
Do ponto de vista biológico, o aterro sanitário corresponde a um sistema dinâmico que envolve reações metabólicas em um ambiente formado pela massa de resíduos, em que cada estágio depende da criação de um ambiente favorável pelo estágio antecedente, que estabelecerá as condições necessárias para que a microbiota execute o processo de degradação. As comunidades microbianas presentes nos aterros sanitários incluem bactérias hidrolíticas e fermentativas, acidogênicas,

\section{口-}

'Secretaria de Estado da Saúde - Blumenau (SC), Brasil.

2Instituto Federal de Educação, Ciência e Tecnologia da Paraíba - Santa Rita (PB), Brasil.

${ }^{3}$ Departamento de Engenharia Civil, Universidade Federal de Campina Grande - Campina Grande (PB), Brasil.

${ }^{4}$ Departamento de Engenharia Sanitária e Ambiental, Universidade Estadual da Paraíba - Campina Grande (PB), Brasil.

*Autora correspondente: kelliannyoaires@hotmail.com

Recebido: 24/09/2018 - Aceito: 24/04/2019 - Reg. ABES: 20180141 
acetogênicas e árqueas metanogênicas, além de bactérias redutoras de sulfato, fungos e protozoários (MATA-ALVAREZ, 2002).

A detecção e a identificação de microrganismos, tradicionalmente, são realizadas de acordo com os meios de obtenção de carbono e energia, as exigências nutricionais, o meio de cultivo para seu crescimento e a observação direta por meio do microscópio (KENNEDY, 1999). No entanto, a utilização dessas metodologias fornece informações limitadas, impedindo a detecção de muitos microrganismos não cultiváveis. De acordo com Quintaes et al. (2014), os ensaios moleculares apresentam vantagens de serem altamente específicos e usados para detectar um gene ou sequências de ácidos nucleicos de um organismo particular ou de um grupo de organismos, além de detectar organismos específicos ou grupos taxonômicos amplificados.

O domínio Bacteria abrange uma grande variedade de microrganismos, cada um com o seu próprio genoma, componentes celulares e reações metabólicas, que interagem entre si e com o ambiente de diferentes maneiras (SANTOS; PEIXOTO; ROSADO, 2009). Considerando que toda informação microbiológica dos ecossistemas dos aterros é importante para a avaliação dos processos biodegradativos de resíduos sólidos, o emprego de técnicas de biologia molecular, tais como extração de DNA, reação em cadeia da polimerase (PCR), eletroforese em gel de gradiente com desnaturante (DGGE) e sequenciamento de DNA, são ferramentas valiosas para identificação específica, caracterização da estrutura e da distribuição espacial de populações bacterianas em amostras complexas, inclusive de resíduos sólidos.

Segundo Melo (2003), a microbiologia em aterros sanitários é de fundamental importância, uma vez que a presença de microrganismos nos processos degradativos dos resíduos são de grande interesse para a biotecnologia ambiental. Esses microrganismos possuem estruturas proteicas, as enzimas, que são responsáveis pelo metabolismo e conseguem degradar uma enorme variedade de substâncias naturais de diferentes origens.

A diversidade de bactérias em aterros está intimamente relacionada à heterogeneidade encontrada na massa de RSU aterrada. Nesse contexto, células experimentais consistem em um sistema que simula a disposição final em aterros sanitários e permite o conhecimento do processo de decomposição dos resíduos sob condições conhecidas e/ou controladas. Simular, por meio de células experimentais, o comportamento de um aterro em escala real favorece o estudo dos processos que ocorrem em seu interior, bem como a avaliação do comportamento dos resíduos quanto aos seus aspectos microbiológicos.

De acordo com Monteiro (2003), os microrganismos presentes em uma célula de resíduos podem indicar a evolução do comportamento biodegradativo, isto é, o número de microrganismos pode ser um indicador da fase em que um aterro se encontra. Pode existir uma relação direta entre a quantidade de matéria orgânica presente em uma célula de resíduos, produção de biogás, recalques, agentes tóxicos, entre outros (MELO, 2003).

Diversos trabalhos têm focado na investigação da biodiversidade microbiana nos mais variados ambientes, tais como aterros sanitários, aquíferos contaminados, campos de plantio de arroz, sedimentos de lagos e reatores anaeróbios (CASAMAYOR et al., 2000; CASSERLY; ERIJMAN, 2003; WATANABE et al., 2004; AKARSUBASI et al., 2005; BUZZINI et al., 2006). Entretanto, poucos estudos moleculares sobre a diversidade microbiana presente em RSU foram realizados, especialmente quando se trata de aterros simulados com resíduos de idades diferentes e em condições peculiares ao semiárido brasileiro, visto que a diversidade microbiana, assim como aspectos funcionais, varia em função de fatores abióticos.

O objetivo deste trabalho foi caracterizar a diversidade bacteriana associada à biodegradação de RSU em uma célula experimental, localizada no município de Campina Grande, Paraíba. Diante deste estudo envolvendo abordagens moleculares, tais resultados visam contribuir com o desenvolvimento de alternativas tecnológicas que permitam maior eficiência nos processos biodegradativos, sugerindo que as respostas obtidas com o sequenciamento de bactérias, caracterizadas no processo de digestão anaeróbia, possam servir de premissa para estudos mais específicos, que venham a colaborar com o entendimento das dinâmicas que ocorrem na massa de RSU aterrados.

\section{METODOLOGIA}

\section{Área de estudo e célula experimental}

A pesquisa foi desenvolvida no município de Campina Grande, estado da Paraíba, Brasil. A temperatura média anual é de $22,4^{\circ} \mathrm{C}$ e o clima da região é do tipo semiárido, caracterizado por irregularidades de chuvas, com precipitação pluviométrica média anual inferior a $800 \mathrm{~mm}$, índice de aridez de até 0,5 e risco de seca maior que 60\% (AESA, 2013; BRASIL, 2005; GUEDES, 2018). A geração per capita de RSU é de 0,64 kg.hab ${ }^{-1} \cdot$ dia $^{-1}$, resultando em uma produção em torno de 261 t.dia ${ }^{-1}$ de resíduos (ECOSAM, 2014; ECOSOLO GESTÃO AMBIENTAL DE RESÍDUOS, 2016).

A célula experimental construída na Universidade Federal de Campina Grande (UFCG) possui 2,0 $\mathrm{m}$ de diâmetro interno, 3,5 $\mathrm{m}$ de altura e volume de $11 \mathrm{~m}^{3}$ (Figura 1). É dotada de sistemas de drenagem de líquidos e gases, medidores de nível dos líquidos, de recalque superficial e profundo, e de temperatura ao longo da profundidade. Apresenta ainda 12 pontos de coletas de RSU distribuídos ao longo de seu diâmetro e altura, os quais são definidos em níveis de profundidade superficial, superior, intermediário e inferior.

Visando obter amostras representativas dos RSU de Campina Grande, Paraíba, a célula experimental foi preenchida com resíduos coletados 


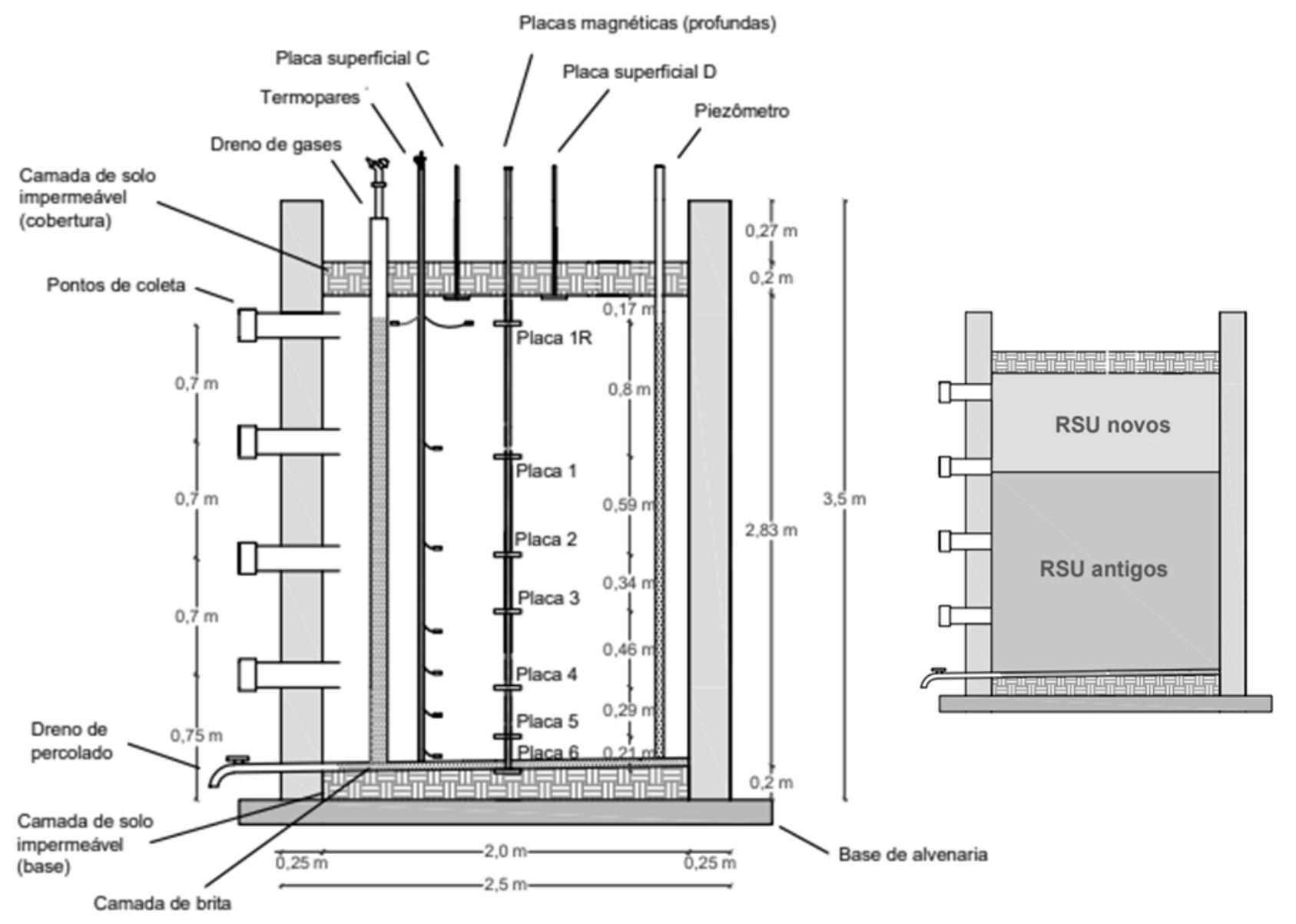

Figura 1 - Configuração da célula experimental de resíduos sólidos urbanos após a retroalimentação.

em locais selecionados a partir de um planejamento estatístico, com nível de confiança de 95\%. Esse planejamento levou em consideração a população dos bairros, as zonas da cidade (Norte, Sul, Leste e Oeste) e a quantidade de RSU produzidos. A partir das quatro zonas da cidade foi realizada uma amostragem estratificada proporcional ao número de bairros existentes em cada zona. Em seguida, por meio de uma amostragem aleatória, foram selecionados os locais de coleta dos RSU. A rota selecionada para a pesquisa compreendeu 12 bairros, totalizando aproximadamente $8,5 \mathrm{t}$ de RSU. O procedimento de coleta seguiu a Norma Brasileira (NBR) 10007 (ABNT, 2004b) - Amostragem de Resíduos.

A célula experimental preenchida com resíduos no ano de 2011 apresentou redução de $50 \%$ em razão dos recalques acentuados (deformações verticais na massa de RSU). Dessa forma, no ano de 2015 foi verificada a necessidade de manutenção da célula experimental por meio de reparos construtivos, com a inserção de nova instrumentação e uma camada de RSU reposta - procedimento que foi denominado de retroalimentação. Cabe destacar que essa operação é comum na rotina de aterros sanitários.
Dessa forma, a distribuição dos resíduos na célula experimental consiste de resíduos antigos e novos. Os resíduos antigos correspondem ao enchimento realizado em setembro de 2011 e a retroalimentação com resíduos novos foi realizada em abril de 2015. A amostragem dos RSU coletados seguiu a mesma configuração do primeiro enchimento da célula. Os resultados contemplados para esta pesquisa representam o monitoramento da célula experimental apenas após o processo de retroalimentação. As amostras da célula experimental (Figura 1) para caracterização bacteriana foram extraídas nas profundidades superior e inferior (2,15 e 0,75 m), constituindo-se de resíduos novos e antigos.

\section{Extração de DNA}

As amostras coletadas nos diferentes níveis (superior e inferior) da célula experimental foram picotadas e imersas em $1.000 \mathrm{~mL}$ de água destilada, por $30 \mathrm{~min}$, para obtenção do extrato líquido, procedimento recomendado pela NBR 10006 (ABNT, 2004a). Com base nas amostras coletadas, inicialmente, duas metodologias foram testadas na preparação das amostras para extração de DNA: filtração e centrifugação. 
O procedimento de filtração (Lab1000, modelo LM-300) consistiu em separar $200 \mathrm{~mL}$ do extrato de lixiviado e dividir em duas alíquotas de $100 \mathrm{~mL}$ cada. Para cada alíquota foram realizadas três pré-filtragens, uma com filtro médio (Whatman Schleicher \& Schuell, US) e duas com membrana de 0,45 $\mu \mathrm{m}$ de porosidade (Whatman Schleicher \& Schuell, US), ambas a fim de remover os sólidos em suspensão. A extração do DNA foi realizada a partir do material depositado no filtro de $0,45 \mu \mathrm{m}$ de porosidade resultante das duas últimas filtrações.

O procedimento de centrifugação (Quimis, modelo Q222TM104) consistiu em transferir $50 \mathrm{~mL}$ do extrato de lixiviado para tubos cônicos estéreis, tipo falcon, sendo coletados $25 \mathrm{~mL}$ de cada nível da célula experimental. A centrífuga foi programada para $4000 \mathrm{~g}$, por $30 \mathrm{~min}$, a $20^{\circ} \mathrm{C}$, para separação da fração líquida. Em seguida, o sobrenadante foi descartado e o material centrifugado foi conduzido à balança analítica para pesagem de $0,5 \mathrm{~g}$ da fração sedimentada.

Para extração de DNA dos RSU previamente preparados (filtração e centrifugação) foi utilizado o Kit Power Soil DNA Isolation (MOBIO Laboratories). O protocolo seguiu as recomendações do fabricante que acompanha o kit. As amostras de DNA foram quantificadas e analisadas quanto à concentração $(n g / \mu \mathrm{L})$ e à pureza expressa pela razão $\mathrm{A}_{260 / 280}$, por meio da análise da densidade óptica em espectrofotômetro NanoDrop 2000 (Thermo Fisher Scientific Inc).

A eletroforese foi realizada em gel de agarose 1\%, em tampão TrisAcetato-EDTA (TAE) $1 \mathrm{X}$ a $100 \mathrm{~V}$, por $90 \mathrm{~min}$. O marcador utilizado foi o $1 \mathrm{~Kb}$ Plus DNA Ladder (Invitrogen). A visualização do gel de agarose foi realizada no transiluminador, modelo L-Pix (Loccus Biotecnologia).

\section{Reação em cadeia da polimerase, eletroforese em gel de gradiente com desnaturante e sequenciamento}

Após a extração de DNA, as amostras foram submetidas à técnica de PCR, para amplificação dos genes que codificam a região 16S do RNA ribossomal de bactérias, com primers universais $27 \mathrm{~F} \mathrm{e} \mathrm{1492R.} \mathrm{Em} \mathrm{seguida,}$ foi realizada a Nested PCR com os primers 341F e 534R (Tabela 1).

O mix de cada PCR continha volume de $20 \mu \mathrm{L}$, sendo: $2 \mu \mathrm{L}$ de DNA, $2 \mu \mathrm{L}$ de tampão 10X (Invitrogen), $0,4 \mu \mathrm{L} \mathrm{MgCl}_{2} 50 \mathrm{mM}$ (Invitrogen), $1 \mu \mathrm{L}$ de dNTPs (Invitrogen), $4 \mu \mathrm{L}$ DMSO 20\%, $1 \mu \mathrm{L}$ de cada primer

Tabela 1 - Sequências de primers universais utilizados para o domínio Bacteria.

\begin{tabular}{|c|c|c|c|}
\hline & Primer & PCR & Sequências nucleotídicas \\
\hline \multirow{4}{*}{$\begin{array}{l}\frac{0}{\Delta} \\
\frac{d}{U} \\
\frac{\pi}{0}\end{array}$} & $27 \mathrm{~F}$ & 1a PCR & AGAGTTTGATCCTGGCTCAG \\
\hline & 1492R & 1a PCR & TACCTTGTACGACT \\
\hline & $341 F$ & 2a PCR & $\begin{array}{l}\text { CGCCCGCCGCGCGCGGCGGGCGGGGCGGGG } \\
\text { GCACGGGGGGACTCCTACGGGAGGCAGCAG }\end{array}$ \\
\hline & $534 \mathrm{R}$ & 2a PCR & ATTACCGCGGCTGCTGG \\
\hline
\end{tabular}

PCR: reação em cadeia da polimerase. (forward e reverse), 0,2 $\mu \mathrm{L}$ de Taq DNA polimerase (Invitrogen) e 8,4 $\mu \mathrm{L}$ de água ultrapura estéril (MilliQ). As amplificações foram realizadas no termociclador (Apllied Biosystems Thermal Cyclers). O programa de amplificação adotado foi 2 min a $95^{\circ} \mathrm{C}$ (desnaturação inicial), 35 ciclos de $30 \mathrm{~s} \mathrm{a} 94^{\circ} \mathrm{C}$ (desnaturação), $30 \mathrm{~s}$ a $55^{\circ} \mathrm{C}$ (anelamento), 1 min e $30 \mathrm{~s} \mathrm{a}$ $72^{\circ} \mathrm{C}$ (extensão) e, finalmente, 5 min a $72^{\circ} \mathrm{C}$ (extensão final).

Em seguida, $10 \mu \mathrm{L}$, produtos de PCR obtidos a partir das amostras de RSU, foram submetidos à DGGE. A solução do gel foi feita segundo o protocolo de Muyzer, Wall e Uitterlinden (1993). A corrida ao longo do gel foi realizada a $60^{\circ} \mathrm{C}$ e $80 \mathrm{~V}$, em cerca de $7 \mathrm{~L}$ de tampão TAE $0,5 \mathrm{X}$ durante $17 \mathrm{~h}$, e o marcador molecular utilizado foi o $1 \mathrm{~Kb}$ Plus DNA Ladder (Invitrogen). Ao final da eletroforese, o gel foi corado por 20 min em solução contendo $60 \mu \mathrm{L}$ de gel red concentrado, $200 \mu \mathrm{L}$ de água deionizada, $4 \mu \mathrm{L}$ de $\mathrm{NaCl} 5 \mathrm{M}$. A visualização do gel de agarose foi realizada no transiluminador, modelo L-Pix (Loccus Biotecnologia).

As imagens digitalizadas dos géis de DGGE foram analisadas com o auxílio do pacote de programas Bionumerics 7.0 (Applied Maths, $\mathrm{BE})$. A partir do perfil de bandas apresentado nos géis, uma matriz de similaridade foi calculada, e com o método de classificação hierárquico foram gerados os dendrogramas.

A preparação das amostras para o sequenciamento consistiu em reamplificar as bandas dos géis de DGGE com os pares de primers utilizados na $2^{\text {a }}$ PCR (Tabela 1 ), em volumes de $50 \mu \mathrm{L}$ que continham: $2 \mu \mathrm{L}$ da $1^{\text {a PCR, }} 5 \mu \mathrm{L}$ de tampão $10 \mathrm{X}$ (Invitrogen), $2 \mu \mathrm{L} \mathrm{MgCl}_{2} 50 \mathrm{mM}$ (Invitrogen), $2 \mu \mathrm{L}$ de DNTPs (Invitrogen), 2,0 $\mu \mathrm{L}$ DMSO 20\%, 0,5 Hi-Di formamida, $2,0 \mu \mathrm{L}$ de cada primer (forward e reverse), $0,2 \mu \mathrm{L}$ de Taq DNA polimerase (Invitrogen) e 32,3 $\mu \mathrm{L}$ de água ultrapura (Milli-Q). O programa de ciclos adotado foi o mesmo da $1^{\text {a }}$ PCR.

Posteriormente, foi realizada a eletroforese em gel de agarose na concentração de $1 \%$, contendo $5 \mu \mathrm{L}$ de brometo de etídio. Foram inoculados em cada poço $4 \mu \mathrm{L}$ de tampão de amostra (TA) e $50 \mu \mathrm{L}$ da Nested-PCR. A fonte utilizada para corrida eletroforética foi programada para uma tensão elétrica de $80 \mathrm{~V}$, uma corrente elétrica de $500 \mathrm{~mA}$, potência de $100 \mathrm{~W}$, por $80 \mathrm{~min}$. O marcador utilizado foi o Low Mass DNA Ladder (Invitrogen). O material aplicado no gel de agarose, após a eletroforese, foi visualizado em luz ultravioleta e fotodocumentado por meio de um transiluminador, modelo L-Pix (Loccus Biotecnologia).

As bandas visíveis no gel de agarose, resultantes da Nested PCR, foram excisadas e eluídas para purificação com o kit Wizard DNA Clean-Up System (Qiagen), seguindo o protocolo recomendado pelo fabricante. Os produtos de PCR, uma vez purificados e quantificados em espectrofotômetro NanoDrop 2000 (Thermo Fisher Scientific Inc), foram sequenciados no Núcleo de Biologia Aplicada da Embrapa Milho e Sorgo, em Sete Lagoas, Minas Gerais.

A caracterização microbiana foi realizada por comparação das sequências publicadas no banco de dados Basic Local Alignment Search Tool (BLAST), nucleotide (n), considerando a identidade acima de $98 \%$. 


\section{RESULTADOS E DISCUSSÃO}

\section{Extração, quantificação, reação em cadeia da polimerase e eletroforese em gel de gradiente com desnaturante}

A quantificação de DNA extraído com o Kit Power Soil DNA Isolation, por filtração e centrifugação das amostras de RSU, está apresentada na Tabela 2.

De acordo com a Tabela 2, as amostras de RSU quantificadas apresentaram concentrações variando de 4,1 a $18,0 \mathrm{ng} / \mu \mathrm{L}$, com média de 11,8 ng/ $\mu \mathrm{L}$. Observa-se ainda um elevado coeficiente de variação $(43,5 \%)$, indicando alta dispersão entre as amostras. Para Solléro et al. (2004), são consideradas concentrações ideais aquelas acima de $10 \mathrm{ng} / \mu \mathrm{L}$ após o processo de extração. As amostras superior (S) e inferior (I) obtidas pela centrifugação e as resultantes da primeira filtração $\left(1^{\circ}\right.$ filtro superior $-1 \mathrm{~S}$ e $1^{\circ}$ filtro inferior $-1 \mathrm{I}$ ) atingiram concentrações acima do valor recomendado.

Menores concentrações de DNA foram observadas nas amostras $2^{\circ}$ filtro superior $-2 S(7,5 \mathrm{ng} / \mu \mathrm{L})$ e $2^{\circ}$ filtro inferior $-2 \mathrm{I}(4,1 \mathrm{ng} / \mu \mathrm{L})$, demonstrando perdas de ácidos nucleicos na segunda filtração, enquanto maior rendimento do DNA foi obtido pelo processo de centrifugação, nas amostras I (18,0 ng/ $\mu \mathrm{L})$ e $S(15,4 \mathrm{ng} / \mu \mathrm{L})$.

Durante os testes realizados pelo método de filtração com membranas de $0,45 \mu \mathrm{m}$ foi observado que, na maioria das vezes, as membranas eram rompidas com o processo de raspagem. Como a extração de DNA era realizada com material depositado no filtro, esse método de preparação das amostras de RSU se tornou inviável, por haver muitas perdas durante o processo e menor rendimento na quantificação do DNA extraído. Entretanto, Santos (2010) utilizou o mesmo procedimento e obteve bons resultados, com a extração de DNA de bactérias presentes no lixiviado dos aterros sanitários de Gramacho, Rio de

Tabela 2 - Quantificação de DNA das amostras de resíduos sólidos urbanos (filtração e centrifugação).

\begin{tabular}{l|c|c}
\hline Amostras & DNA ng/ $\mu \mathrm{L}$ & $\mathrm{A}_{260 / 280}$ \\
\hline Superior (S) & 15,40 & 1,93 \\
\hline Inferior (I) & 18,00 & 1,77 \\
\hline 10 filtro superior (1S) & 13,60 & 2,02 \\
\hline 10 filtro inferior (11) & 12,40 & 2,03 \\
\hline 20 filtro superior (2S) & 7,50 & 1,93 \\
\hline 20 filtro inferior (2I) & 4,10 & 2,22 \\
\hline Máximo & 18,00 & 2,22 \\
\hline Mínimo & 4,10 & 1,77 \\
\hline Média & 11,80 & 1,98 \\
\hline Desvio padrão & 5,15 & 0,15 \\
\hline Coeficiente de variação (\%) & 43,55 & 7,50 \\
\hline
\end{tabular}

Janeiro; Gericinó, Rio de Janeiro; Morro do Céu, Rio de Janeiro; Nova Iguaçu, Rio de Janeiro; e Muribeca, Pernambuco.

Diante dos testes realizados, o processo de centrifugação foi considerado mais adequado para preparação das amostras de RSU, visto que esse procedimento foi realizado de forma mais rápida, teve menor custo e maior rendimento do DNA após a extração, quando comparado à técnica de filtração.

A pureza expressa pela razão $A_{260 / 280}$ indica o nível de contaminação nas amostras. Em DNAs livres de impurezas por proteínas, a relação $A_{260 / 280}$ esperada como satisfatória deve estar entre 1,8 e 2,0 (SAMBROOK; RUSSEL, 2001; BRITO et al., 2004).

Na Tabela 2, os resultados oscilaram de 1,7 a 2,2, com média de 2,0 , em relação à pureza das amostras. Observou-se que as amostras I, 1S, 1I e 2I não ficaram na faixa considerada ideal, indicando uma leve contaminação por proteínas após a extração do DNA, o que poderia diminuir a eficiência de amplificação na PCR, o que não ocorreu. Cabe destacar que o processo de purificação poderia elevar a pureza do DNA e diminuir a contaminação das amostras I, 1S, 1I e 2I. Contudo, esse procedimento foi realizado na etapa que precede o sequenciamento do DNA, para todas as amostras.

A comunidade de bactérias presente nos RSU da célula experimental derivados da PCR-DGGE está representada no perfil de bandas da Figura 2. O critério de escolha das bandas levou em consideração a visualização em transiluminador UV. Dessa forma, foram selecionadas seis bandas, destacadas e identificadas como 1B, 2B, 3B, 4B, 5B e 6B.

Normalmente, considera-se cada banda da DGGE como uma espécie microbiana. Porém, muitas bactérias podem apresentar diferentes mobilidades no gel com gradiente desnaturante, resultando em múltiplas bandas da mesma espécie microbiana (BOON et al., 2000). É importante ressaltar que a técnica de DGGE, quando realizada com primers universais, é capaz de detectar apenas as populações mais abundantes nas amostras

Analisando a Figura 2, podem-se inferir diferenças pouco significativas entre os níveis da célula experimental, sugerindo, equivocadamente, que os mesmos microrganismos estavam presentes nas amostras de RSU dos níveis S e I. Costa, Vaz-Pires e Bernardo (2006) enfatizaram que os pontos de coleta se referem a locais com grandes variações de fatores ambientais e bióticos, tais como a estrutura do solo, as variáveis físico-químicas, a disponibilidade de nutrientes, o conteúdo de matéria orgânica e as condições climáticas locais. Todos esses fatores têm papel na dinâmica da comunidade microbiana (GARBEVA; VAN VEEN; VAN ELSAS, 2004).

Dessa forma, dendrogramas foram elaborados a partir das análises conclusivas da DGGE, com o objetivo de verificar a similaridade entre populações de bactérias nas amostras de RSU. A similaridade foi determinada com base na presença ou ausência das bandas detectadas no gel, considerando as semelhanças entre os padrões de bandas, 


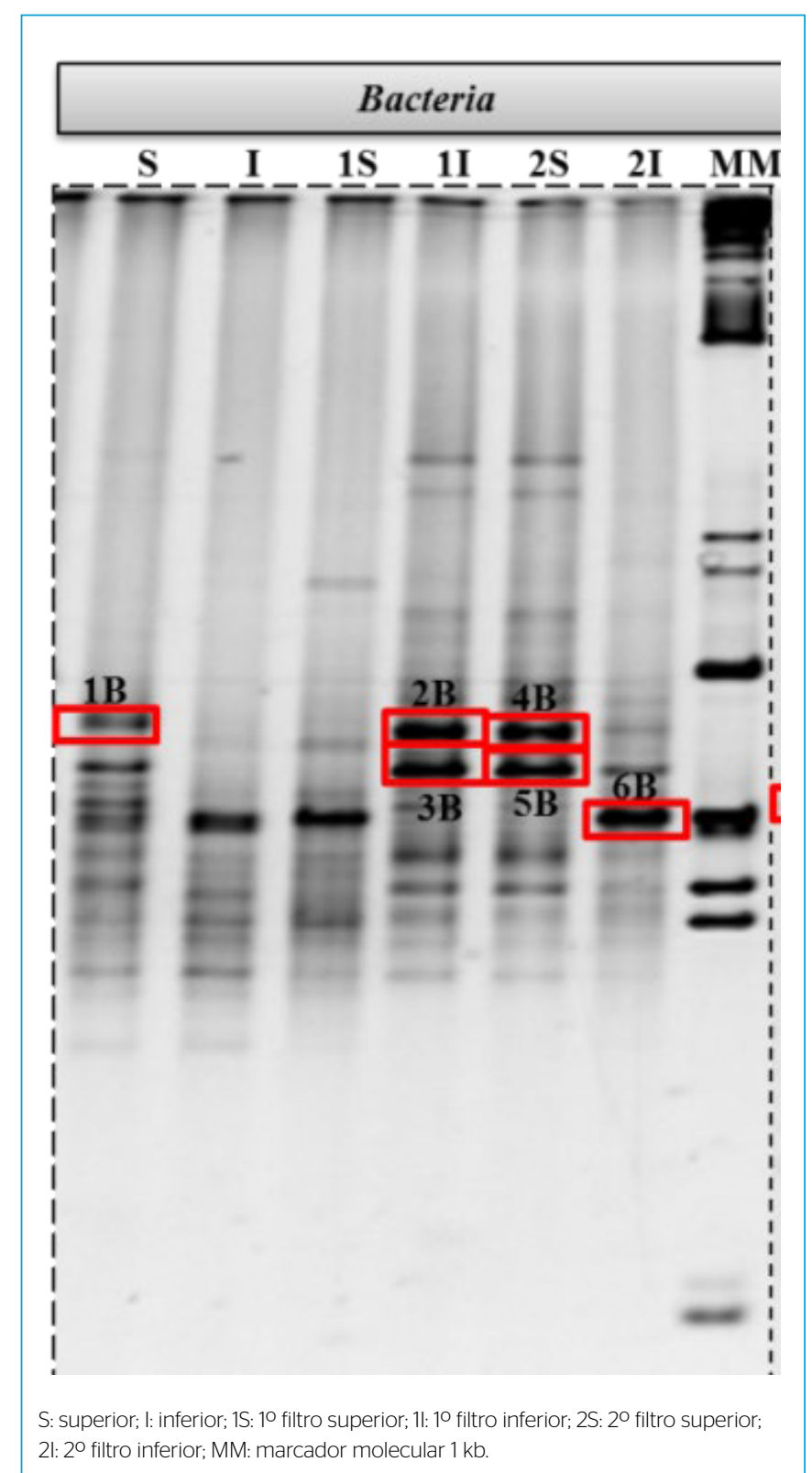

Figura 2 - Perfil dos produtos da reação em cadeia da polimerase-eletroforese em gel de gradiente com desnaturante. tomadas em pares, que podem ser expressas em um valor percentual (DÍEZ et al., 2001).

O dendrograma gerado a partir dos valores de similaridade, obtido com o perfil de bandas de DGGE para o domínio Bacteria das amostras S, I, 1S, 1I, 2S e 2I da célula experimental de RSU, pode ser observado na Figura 3.

Na Figura 3, o dendrograma apresentou um cluster principal com coeficiente de similaridade de 70\%. Nesse caso, a comunidade microbiana preexistente na célula experimental sofreu alteração nos níveis I e $\mathrm{S}$ e nos diferentes métodos de preparação das amostras para extração.

Pode-se observar que, do grande cluster com $70 \%$ de similaridade, se formaram dois agrupamentos distintos (A e B), unindo no grupo A as amostras 1I e 2S, com coeficiente de similaridade de $97 \%$, sendo diferenciado em $3 \%$ com o surgimento de uma nova banda na amostra $1 \mathrm{I}$.

O grupo B, composto de 1S, S, I e 2I, apresentou coeficiente de similaridade de $81 \%$ entre si. Esse agrupamento mostrou, ainda, dois subgrupos, "c" e "d". O subgrupo c apresentou coeficiente de similaridade na ordem de $91 \%$. Essa diferença surgiu em função de uma banda a mais e, ainda, a perda de outra, em posições diferentes. O subgrupo d obteve um coeficiente de similaridade entre as amostras S, I e 2I de $87 \%$.

De modo geral, verificou-se que a similaridade entre as camadas superior e inferior da célula experimental pode ser considerada elevada, embora os RSU sejam de idades diferentes. Diante dessa circunstância, pode-se inferir que as mesmas populações de bactérias podem ser encontradas nos diferentes níveis da célula experimental. Isso acontece, provavelmente, aos fatores de lixiviação, ocasionados pela biodegradação da matéria orgânica e pelas precipitações que podem carrear esses microrganismos para o nível I da célula experimental.

\section{Caracterização da diversidade bacteriana}

De acordo com os perfis resultantes do DGGE obtidos na Figura 2, foram selecionadas seis bandas para o sequenciamento domínio Bacteria - as filiações foram determinadas por comparação com as depositadas no GenBank. As bandas 1B, 2B, 3B, 4B, 5B e 6B estão indicadas na Tabela 3.

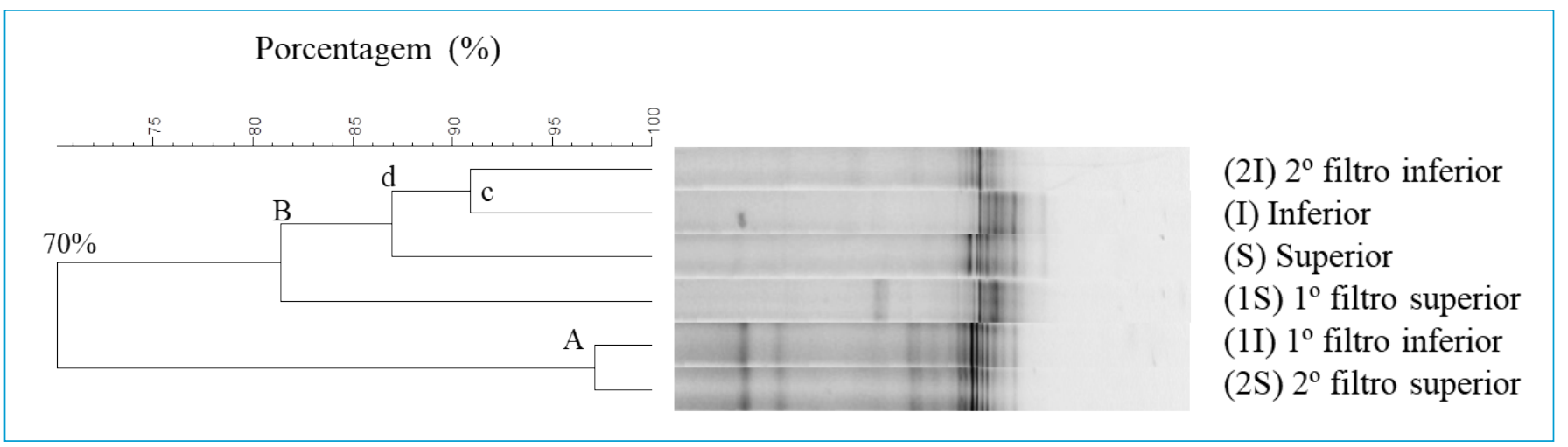

Figura 3 - Dendrograma das amostras superior, inferior, $1^{\circ}$ filtro superior, $1^{\circ}$ filtro superior, $2^{\circ}$ filtro superior e $2^{\circ}$ filtro inferior. 
Tabela 3 - Identidade dos microrganismos: Domínio Bacteria.

\begin{tabular}{|c|c|c|c|c|}
\hline \multicolumn{5}{|c|}{ Bacteria } \\
\hline Amostra & Banda & Definição & Identidade & GenBank \\
\hline Superior (S) & 1B & $\begin{array}{c}\text { Uncultured } \\
\text { Pseudomonas sp. }\end{array}$ & $\begin{array}{c}99 \% \\
(354 / 357)\end{array}$ & JX527024.1 \\
\hline $\begin{array}{l}10 \text { filtro } \\
\text { inferior (11) }\end{array}$ & $2 \mathrm{~B}$ & $\begin{array}{l}\text { Uncultured } \\
\text { bacterium }\end{array}$ & $\begin{array}{c}98 \% \\
(427 / 435)\end{array}$ & JF964694.1 \\
\hline $\begin{array}{l}10 \text { filtro } \\
\text { inferior (11) }\end{array}$ & 3B & Enterobacter sp. & $\begin{array}{c}99 \% \\
(358 / 361)\end{array}$ & HQ268733.1 \\
\hline $\begin{array}{l}20 \text { filtro } \\
\text { superior (2S) }\end{array}$ & $4 \mathrm{~B}$ & $\begin{array}{c}\text { Klebsiella } \\
\text { pneumoniae }\end{array}$ & $\begin{array}{c}99 \% \\
(357 / 361)\end{array}$ & JN644624.1 \\
\hline $\begin{array}{l}20 \text { filtro } \\
\text { superior (2S) }\end{array}$ & $5 B$ & Enterobacter sp. & $\begin{array}{c}98 \% \\
(203 / 209)\end{array}$ & HQ268733.1 \\
\hline $\begin{array}{l}20 \text { filtro } \\
\text { inferior (2l) }\end{array}$ & $6 B$ & $\begin{array}{l}\text { Uncultured } \\
\text { Bacillus sp. }\end{array}$ & $\begin{array}{c}99 \% \\
(398 / 401)\end{array}$ & KF722674.1 \\
\hline
\end{tabular}

O resultado obtido no sequenciamento da banda $1 \mathrm{~B}$ da amostra S da célula experimental de RSU apresentou 99\% de identidade com a bactéria não cultivável Pseudomonas sp. (JX527024.1). Esse gênero bacteriano pertence ao filo Proteobacteria e pode se desenvolver em ampla gama de habitats, principalmente na água e em solos úmidos (BREATHNACH et al., 2012).

Pseudomonas também são capazes de se desenvolver em lixiviado de aterro. Dessa forma, a presença dessas populações pode ser discutida no que tange à saúde pública. Quintaes et al. (2014) observaram que as análises microbianas de uma célula de aterro sanitário revelaram grande número de bactérias patogênicas e oportunistas, muitas delas pertencentes aos gêneros Enterobacter, Escherichia, Klebsiella, Salmonella, Pseudomonas e Staphylococcus (EFUNTOYE; BAKARE; SOWUNMI, 2011; ZHANG; KEAT; GERSBERG, 2010).

Presume-se que as Pseudomonas tenham participado no processo biodegradativo, disponibilizando substratos para as árqueas metanogênicas por meio das fases de hidrólise, acidogênese e acetogênese. Segundo Xie et al. (2011), o estudo da comunidade bacteriana oriunda de um aterro sanitário revelou a predominância das bactérias sobre os demais microrganismos, destacando as Pseudomonas como as responsáveis pela remoção de poluentes e pela elevada taxa de biodegradação orgânica.

Para Beal e Betts (2000), os gêneros Pseudomonas e Acinetobacter são capazes de mineralizar muitos dos compostos aromáticos recalcitrantes presentes em RSU. Lalucat et al. (2006) detectaram no lixiviado de aterros sanitários que esse gênero participa dos processos de degradação e desnitrificação da matéria orgânica.

Nesse contexto, membros do gênero Pseudomonas são importantes em ambiente com resíduos sólidos, como aterros sanitários e células experimentais, porque podem elevar as taxas de biodegradação, inclusive de resíduos antigos. Cabe destacar que a caracterização de bactérias em RSU proporciona maior entendimento dos processos biodegradativos e, consequentemente, a otimização de cada fase desse processo, podendo contribuir para a aceleração do tempo de estabilização da matéria orgânica putrescível, que permite o aterramento de novos RSU, quando o objetivo foi o aproveitamento de áreas, e maior produção de biogás, quando se almeja o aproveitamento energético.

$\mathrm{Na}$ banda 2B, resultante da primeira filtração do nível I (1I) da célula experimental, foi caracterizada uma bactéria não cultivável (JF964694.1), descrita por Huang e Zhang (2013), que avaliaram em diferentes regiões geográficas a microbiota de larvas de um tipo de besouro (Coleoptera) e como esses organismos respondiam à heterogeneidade ambiental.

Sabe-se que em resíduos sólidos é comum a presença de coleópteros (besouro, escaravelho, joaninha, potó, vaga-lume, entre outros), que se alimentam de organismos mortos ou de materiais parcialmente em decomposição. Esses organismos detritívoros são de fundamental importância para a cadeia alimentar, porque promovem a degradação inicial da matéria orgânica, facilitando a quebra de compostos para fungos e bactérias na massa de resíduos.

As bandas 3B e 5B das amostras $1 \mathrm{I}$ e $2 \mathrm{~S}$ da célula experimental de RSU apresentaram 99\% de identidade com a bactéria Enterobacter sp. (HQ268733.1). Membros desse gênero, que também pertencem ao filo Proteobacteria, são classificados como anaeróbios facultativos e quimiorganotróficos, tendo tanto o metabolismo aeróbio quanto o fermentativo, podendo ser encontrados em ambientes como água, solo, esgoto e fezes humanas.

Na digestão anaeróbia, a conversão de diversos ácidos e álcoois dá início à fase acetogênica, em que a função das bactérias é a produção de substratos que serão metabolizados pelas árqueas metanogênicas. Apine e Jadhav (2011) citam o gênero Enterobacter como um dos principais produtores de ácidos graxos.

De acordo com Carbone et al. (2002), Enterobacter spp. são bactérias fermentadoras ativas que podem produzir ácido graxo e ácido láctico, e que, por isso, estão entre os organismos responsáveis pela primeira etapa na bioconversão de hidratos de carbono a $\mathrm{CH}_{4}$. De acordo com Takayanagui et al. (2007), algumas espécies podem ainda solubilizar fosfato e atuar degradando amido e celulose.

Enterobacter spp. encontradas referem-se a amostras dos níveis $\mathrm{S}$ e I da célula experimental de RSU, sendo membros desse gênero indicadores de contaminação entérica, visto que pertencem ao grupo dos coliformes termotolerantes, que estão presentes nas fezes de animais de sangue quente e na degradação de matéria orgânica. Aires et al. (2017) encontraram nas amostras de RSU da célula experimental fraldas descartáveis contendo excrementos, o que pode ter contribuído para a presença desse gênero. Carvalho, Jesus e Portella (2010) verificaram que os gêneros Enterobacter e Escherichia estão entre os principais microrganismos que colonizam o trato gastrointestinal de recém-nascidos. 
A banda 4B é referente à segunda filtração do nível S (2S) da célula experimental de RSU e apresentou 99\% de identidade com a bactéria Klebsiella pneumoniae (JN644624.1), espécie que também pertence ao filo Proteobacteria.

A Klebsiella pneumoniae tem sido uma das bactérias mais importantes associadas às infecções hospitalares, sendo muito comuns em infecções do trato urinário, do trato respiratório, abscessos do fígado e bacteremias. Essa espécie bacteriana tem merecido destaque, principalmente, para o desenvolvimento de resistência a alguns antimicrobianos (SUN et al., 2006; DEBBY et al., 2012). A detecção dessas bactérias no ambiente é importante para avaliar o potencial biodegradativo, os perfis de resistência bacteriana do local analisado e identificar as possíveis rotas de contaminação e disseminação desses agentes.

De acordo com Odeyemi, Aderiye e Bamidele (2013) e Tomassoni et al. (2014), Klebsiella pneumoniae são bactérias versáteis na utilização de substratos e têm a capacidade de se adaptarem às condições tóxicas dos RSU.

Bactérias como Klebsiella, Pseudomonas e Bacillus apresentam capacidade lipolítica, sugerindo a aplicação destas no pré-tratamento de resíduos ricos em lipídeos, podendo, ainda, serem utilizadas nos processos de biorremediação de solos (ODEYEMI; ADERIYE; BAMIDELE, 2013). As bactérias lipolíticas podem catalisar a hidrólise de lipídeos em moléculas miscíveis e ainda consumir os produtos como fontes de carbono (HASANUZZAMAN et al., 2004).

Um dos principais problemas encontrados em áreas de aterros é o alto teor de metais pesados no solo e na vegetação. Os metais pesados como arsênio $(\mathrm{As})$, níquel $(\mathrm{Ni})$, cobre $(\mathrm{Cu})$, zinco $(\mathrm{Zn})$, cádmio $(\mathrm{Cd})$, chumbo $(\mathrm{Pb})$, mercúrio $(\mathrm{Hg})$ e cromo $(\mathrm{Cr})$ estão presentes em diversos tipos de resíduos dispostos em aterros, como lâmpadas, pilhas, baterias, restos de tintas, latas, entre muitos outros produtos com substâncias tóxicas presentes (SISINNO; MOREIRA, 1996; HYPOLITO; EZAKI, 2006; XIAOLI et al., 2007; ANICETO; HORBE, 2012).

Bactérias que degradam a matéria orgânica são sensíveis à presença de metais pesados, cujas concentrações são frequentemente encontradas em RSU, podendo prejudicar o processo biodegradativo. Liu et al. (2018) indicaram que a Klebsiella pneumoniae teve a capacidade de se adaptar a ambientes com a presença de metais pesados, incluindo $\mathrm{Cd}, \mathrm{Hg}$, As e Cr. Vale ressaltar que metais como Cd, $\mathrm{Pb}, \mathrm{Cu}, \mathrm{Zn}$ e Ni são encontrados nos RSU e podem elevar os níveis de contaminação do solo e das águas (ZHENG et al., 2013; HUANG; ZHANG, 2013).

Vários autores indicam o processo de contaminação de metais pesados com os compartimentos adjacentes às áreas de deposição de resíduos sólidos. Com excesso de concentração de metais pesados no material constituinte de um aterro, pode haver a migração desses por meio do processo de lixiviação. A lixiviação é o processo físico no qual os líquidos presentes nos resíduos sólidos são liberados durante o processo de decomposição e, depois, migram pelo perfil do solo. Com a infiltração de águas da chuva, esse líquido pode permear as camadas de fundo dos locais de disposição e contaminar as águas subterrâneas. Também pode ser transportado superficialmente para os mananciais próximos e, dessa forma, possibilitar a entrada dos metais na cadeia alimentar e, consequentemente, o acúmulo e a contaminação do fator biótico (OLIVEIRA; JUCÁ, 2004; JAIN; KIM; TOWNSEND, 2005; KORF et al., 2008).

Silva (2016) encontrou na mesma célula experimental de RSU deste estudo concentrações de $\mathrm{Ni}, \mathrm{Cd}, \mathrm{Cr}$ e $\mathrm{Pb}$ acima dos valores estabelecidos pela NBR 10004/2004, sugerindo o enquadramento dos resíduos como Classe I (perigosos). Bactérias ambientais comuns, como a Klebsiella pneumoniae, apesar de parte delas serem patogênicas, são, em sua maioria, seguras para aplicações biotecnológicas, tornando-se importantes não só para degradar os lipídeos, mas também para tolerar a presença de metais pesados, podendo ser uma ferramenta útil para tratar resíduos industriais (ODEYEMI; ADERIYE; BAMIDELE, 2013).

Finalmente, o resultado obtido no sequenciamento da banda $6 \mathrm{~B}$, resultante da segunda filtração do nível I (2I) da célula experimental de RSU, apresentou 98\% de identidade com a bactéria não cultivável Bacillus sp. (KF722674.1). Esse gênero bacteriano, pertencente ao filo Firmicutes, tem o solo como habitat principal e desempenha um papel importante no ciclo do carbono e do enxofre.

Várias bactérias acidogênicas têm sido encontradas em reatores anaeróbios e em aterros sanitários, como as pertencentes aos gêneros Bacillus, Clostridium, Pseudomonas e Streptococcus (KEYSER et al., 2006).

Membros do gênero Bacillus possuem capacidade de sintetizar enzimas hidrolíticas, de interesse biotecnológico (ABELL; BOWMAN, 2005). Gorlach-Lira e Coutinho (2007) avaliaram a diversidade microbiana no solo do Cariri paraibano e verificaram que várias bactérias do filo Firmicutes exibiram capacidades celulolíticas, proteolíticas e amiliolíticas, promovendo fermentações a ácidos graxos voláteis ou a outros subprodutos utilizados pelas árqueas metanogênicas (PATEL et al., 2014).

Bacillus apresentam-se distribuídos no solo e possuem vasta capacidade metabólica, podendo persistir em ambientes críticos em relação à temperatura, à umidade, aos agentes químicos e à radiação, como é o caso da célula experimental de RSU. Provavelmente, o gênero Bacillus atuou na célula experimental de RSU nos processos de hidrólise, acidogênese e acetogênese em razão de sua versatilidade na utilização de substratos. Rodríguez e Fraga (1999) descreveram que esse gênero possui, ainda, grande potencial de solubilização de fósforo nos solos e que algumas Bacillus spp. são capazes de degradar hidrocarbonetos.

A análise do sequenciamento do domínio Bacteria, nas amostras de RSU da célula experimental, revelou a presença de dois filos distintos: Proteobacteria e Firmicutes (Figura 4). O filo Proteobacteria apresenta grande diversidade morfológica e fisiológica, e entre as estratégias para 
Bacillus sp. não cultivável $16 \%$

Não cultivável

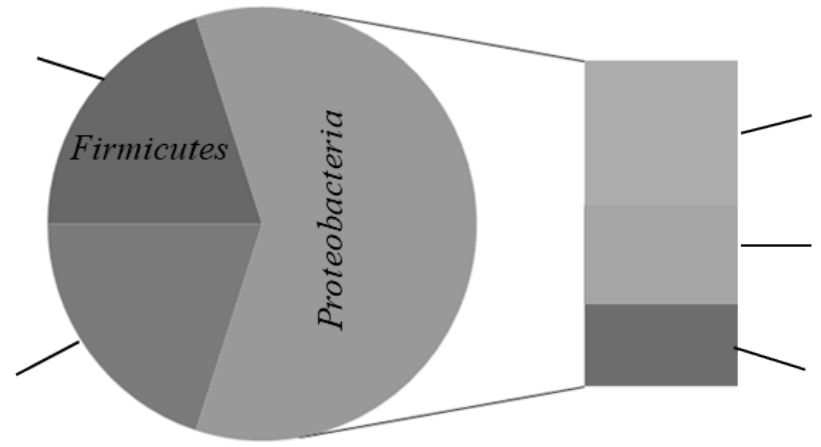

Enterobacter sp. $36 \%$

Pseudomonas $s p$. não cultivável $16 \%$

Klebsiella pneumoniae $16 \%$ $16 \%$

Figura 4 - Representação da distribuição dos filos do domínio Bacteria.

obtenção de energia, são encontrados organismos com metabolismos quimiolitotrófico, quimiorganotrófico e fototrófico, além de outras vias metabólicas (CANHOS et al., 1997).

Níveis abundantes do filo Proteobacteria foram detectados em um aterro sanitário japonês (SAWAMURA et al., 2010) e em rejeitos antigos dos aterros sanitários de Xangai (XIE et al., 2012). Na célula experimental, os resíduos depositados são de idades diferentes. Dessa forma, o filo Proteobacteria pode ter representado função ecológica importante nos resíduos de difícil degradação.

Firmicutes têm a capacidade de degradar ácidos graxos voláteis, tais como o butirato e os seus análogos. Essa degradação produz $\mathrm{H}_{2}$, o qual pode ser degradado pelas metanogênicas hidrogenotróficas. De acordo com Song et al. (2015), que estudaram a diversidade de comunidades bacterianas em aterros sanitários, o filo Firmicutes tem um papel importante na decomposição da celulose, sendo prevalente nos estágios acidogênicos e acetogênicos em razão de sua capacidade de fermentar açúcares e aminoácidos, além da produção dos ácidos acético e láctico (DOLOMAN et al., 2017; KLOCKE et al., 2007).

As bactérias caracterizadas por meio deste estudo são fundamentais nos processos de hidrólise, acidogênese e acetogênese, uma vez que os substratos produzidos, principalmente acetato e hidrogênio, serão metabolizados pelas árqueas metanogênicas, que são responsáveis pela produção de biogás, sobretudo de $\mathrm{CH}_{4}$.

\section{CONCLUSÕES}

A preparação das amostras de RSU pelo processo de centrifugação apresentou maiores rendimentos de DNA após a extração. Por meio da PCR-DGGE foi verificada elevada similaridade das bactérias nas camadas superior e inferior da célula experimental, apesar dos RSU serem de idades diferentes, indicando a influência de fatores externos, como a lixiviação e as precipitações, que podem carrear esses microrganismos para o nível inferior.

A caracterização bacteriana possibilitou encontrar, na célula experimental de RSU, membros em nível de gênero e espécie, alguns ainda não cultiváveis, como Uncultured Pseudomonas sp., Uncultured bacterium, Enterobacter sp., Klebsiella pneumoniae e Uncultured Bacillus $s p$., sugerindo que nos RSU existem representantes ainda desconhecidos e/ou não isolados que participam dos processos de hidrólise, acidogênese e acetogênese.

\section{REFERÊNCIAS}

ABELL, G.C.; BOWMAN, J.P. (2005) Ecological and biogeographic relationships of class Flavobacteria in the Southern Ocean. Microbial Ecology, v. 51, n. 2, p. 265-277. https://doi.org/10.1016/j. femsec.2004.09.001

AGÊNCIA EXECUTIVA DE GESTÃO DAS ÁGUAS DO ESTADO DA PARAÍBA (AESA). AESA, 2013. Disponível em: <http://www.aesa. pb.gov.br/aesa-website/meteorologia-chuvas/climatologia/>. Acesso em: 12 nov. 2013.
AIRES, K.O.; SOUSA, R.B.A.; GUEDES, M.J.F; SANTOS, J.J.N.; MELO, M.C. (2017) Composição física dos resíduos sólidos urbanos na produção de biogás em uma célula experimental. In: CONGRESSO NACIONAL DE PESQUISA E ENSINO EM CIÊNCIAS, 2., 2017. Anais... Campina Grande. 5 p.

AKARSUBASI, A.T.; INCE, O.; KIRDAR, B.; OZ, N.A.; ORHON, D.; CURTIS, T.P.; HEAD, I.M.; INCE, B.K. (2005) Effect of wastewater composition on Archaea population diversity. Water Research, v. 39, n. 8, p. 1576-1584. https://doi.org/10.1016/j.watres.2004.12.041 
ANICETO, K.C.P.; HORBE, A.M.C. (2O12) Solos urbanos formados pelo acúmulo de resíduos em Manaus, Amazonas, Brasil. Acta Amazônica, v. 42, n. 1, p. 135-148. https://doi.org/10.1590/S004459672012000100016

APINE, O.A.; JADHAV, J.P. (2011) Optimization of medium for indole3-acetic acid production using Pantoea agg/omerans strain PVM. Journal of Applied Microbiology, v. 110, n. 5, p. 1235-1244. https://doi. org/10.1111/j.1365-2672.2011.04976.x

ASSOCIAÇÃO BRASILEIRA DE NORMAS TÉCNICAS (ABNT). (2004a) NBR 10006: Procedimento para obtenção de extrato solubilizado de resíduos sólidos. Rio de Janeiro: ABNT. 3 p.

ASSOCIAÇÃO BRASILEIRA DE NORMAS TÉCNICAS (ABNT). (2004b) NBR 10007: Resíduos Sólidos - amostragem de Resíduos. Rio de Janeiro: ABNT.

BEAL, R.; BETTS, W.B. (2000) Role of rhamnolipid biosurfactants in the uptake and mineralization of hexadecane in Pseudomonas aeruginosa. Journal of Applied Microbiology, v. 89, n. 1, p. 158-168. https://doi.org/10.1046/.1365-2672.2000.01104.x

BOON, N.; MARLÉ, C.; TOP, E.M.; VERSTRAETE, W. (2000) Comparison of the spatial homogeneity of physico-chemical parameters and bacterial 16S rRNA genes in sediment samples from a dumping site for dredging sludge. Applied Microbiology and Biotchnology, v. 53, p. 742-747. https://doi.org/10.1007/ s002530000325

BRASIL. (2005) Nova delimitação do semiárido brasileiro. Brasília: Ministério da Integração Nacional.

BREATHNACH, A.S.; CUBBON, M.D.; KARUNAHARAN, R.N; POPE, C.F; PLANCHE, T.D. (2012) Multidrug-resistant Pseudomonas aeruginosa outbreaks in two hospitals: association with contaminated hospital waste-water systems. Journal of Hospital Infection, v. 82, n. 1, p. 19-24. https://doi.org/10.1016/j.jhin.2012.06.007

BRITO, L.G.; HUACCA, M.E.F.; REGITANO, L.C.; BORJA, G.E.M. (2004) Avaliação de diferentes protocolos de extração de DNA celular a partir de adultos de Haematobia irritans (Linnaeus, 1758) (Diptera: Muscidae). Revista Brasileira de Medicina Veterinária, Rio de Janeiro, v. 26, n. 4, p. 168-172.

BUZZINI, A.P.; SAKAMOTO, I.K.; VARESCHE, M.B.; PIRES, E.C. (2006) Evaluation of the microbial diversity in an UASB reactor treating wastewater from an unbleached pulp plant. Process Biochemistry, v. 41, n. 1, p. 168-176. https://doi.org/10.1016/.jprocbio.2005.06.009

CANHOS, V.P.; MANFIO, G.P.; VAZOLLER, R.F; PELLIZARI, V.H. (1997) Diversidade no domínio bactéria. In: JOLY, C.A.; BICUDO, C.E.M. (org.). Biodiversidade do estado de São Paulo, Brasil: síntese do conhecimento ao final do século XX. São Paulo: FAPESP. (Microrganismos \& Vírus, v. 1). p.1-13.

CARBONE, S.R.; SILVA, F.M.; TAVARES, C.R.G.; DIAS FILHO, B.P. (2002) Bacterial population of a two-phase anaerobic digestion process treating effluent of cassava starch factory. Environmental Technology, v. 23, n. 5, p. 591-597. https://doi. org/10.1080/09593332308618386
CARVALHO, J.L.V.; JESUS, S.C.; PORTELLA, R.B. (2010) Composição gravimétrica dos resíduos sólidos domiciliares e comerciais do centro da cidade de barreiras - BAHIA. Revista Chão Urbano, Rio de Janeiro, ano $X$.

CASAMAYOR, E.O.; SHÄFER, H.; BAÑERAS, L.; PEDRÓS-ALIÓ, C.; MUYZER, G. (2O00) Identification of and spatio-temporal differences between microbial assemblages from two neighboring sulfurous lakes: comparison by microscopy and denaturing gradient gel electrophoresis. Applied and Environmental Microbiology, v. 66, n. 2, p. 499-508. https://doi.org/10.1128/aem.66.2.499-508.2000

CASSERLY, C; ERIJMAN, L. (2003) Molecular monitoring of microbial diversity in an $\cup A S B$ reactor. International Biodeterioration \& Biodegradation, v. 52, n. 1, p. 7-12. https://doi.org/10.1016/509648305(O2)00094-X

COSTA, P.M.; VAZ-PIRES, P.; BERNARDO, F. (2006) Antimicrobial resistance in Enterococcus spp. Isolated in inflow, effluent and sludge from municipal sewage treatment plants. Water Research, v. 40, n. 8, p. 1735-1740. https://doi.org/10.1016/j.watres.2006.02.025

DEBBY, B.D; GANOR, O:; YASMIN, M.; DAVID, L; NATHAN, K.; ILANA, T: DALIT, S: SMOLLAN, G:; GALIA, R. (2O12) Epidemiology of carbapenem resistant Klebsiella pneumonia colonization in an intensive care unit. European Journal of Clinical Microbiology and Infectious Diseases, v. 31, n. 8, p. 1811-1817. https://doi.org/10.1007/s10096-011-1506-5

DIEZ, B.C.; PEDRÓS-ALIÓ, T.L.; MARSH, R.M.; MASSANA, R. (2001) Application of denaturing gradient gel electrophoresis (DGGE) to study the diversity of marine picoeukaryotic assemblages and comparison of DGGE with other molecular techniques. Applied Environmental Microbiology, v. 67, n. 7. p. 2942-2951. https://doi. org/10.1128/aem.67.7.2942-2951.2001

DOLOMAN, A.; SOBOH, Y.; WALTERS, A.J; SIMS, R.C.; MILLER, C.D. (2017) Qualitative Analysis of Microbial Dynamics during Anaerobic Digestion of Microalgal Biomass in a UASB Reactor. International Journal of Microbiology, v. 2017, 5291283. https://doi. org/10.1155/2017/5291283

ECOSOLO GESTÃO AMBIENTAL DE RESÍDUOS. (2016) Dados do monitoramento do Aterro Sanitário de Campina Grande: ano 2016. Campina Grande: Ecosolo Gestão Ambiental de Resíduos.

EFUNTOYE, M.O.; BAKARE, A.A.; SOWUNMI, A.A. (2011) Virulence factors and antibiotic resistance in Staphylococcus aureus and Clostridium perfringens from landfill leachate. African Journal of Microbiology Research, v. 5, n. 23, p. 3994-3997. https://doi. org/10.5897/AJMR11.756

EMPRESA DE CONSULTORIA EM SANEAMENTO AMBIENTAL (ECOSAM). (2014) Plano municipal de gestão integrada de resíduos sólidos do município de Campina Grande - PB: Diagnóstico da situação atual dos resíduos sólidos urbanos. Campina Grande: ECOSAM. 289 p.

GARBEVA, P.; VAN VEEN, J.A.; VAN ELSAS, J.D. (2004) Microbial diversity in soil: selection of microbial populations by plant and soil type and implications for disease suppressiveness. Annual Review of Phytopathology, v. 42, p. 243-270. https://doi.org/10.1146/annurev. phyto.42.012604.135455 
GORLACH-LIRA, K.; COUTINHO, H.D.M. (2007) Population dynamics and extracelular enzymes activity of mesophilic and thermophilic bacteria isolated from semi-arid soil of northeastern Brazil. Brazilian Journal of Microbiology, v. 38, n. 1, p. 135-141. https:// doi.org/10.1590/S1517-83822007000100028

GUEDES, M.J.F. (2018) Estudo das emissões de biogás em aterro de resíduos sólidos urbanos no semiárido brasileiro. 181f. Tese (Doutorado em Recursos Naturais) - Centro de Tecnologia e Recursos Naturais, Universidade Federal de Campina Grande, Campina Grande.

HASANUZZAMAN, M.; UMADHAY-BRIONES, K.M.; ZSIROS, S.M.; MORITA, N.; NODASAKA, Y.; YUMOTO, I.; OKUYAMA, H. (2004) Isolation, identification and characterization of a novel, oil-degrading bacterium, Pseudomonas aeruginosa T1. Current Microbiology, v. 49, n. 2, p. 108-114. https://doi.org/10.1007/s00284-004-4267-x

HUANG, S.; ZHANG, H. (2013) The Impact of Environmental Heterogeneity and Life Stage on the Hindgut Microbiota of Holotrichia parallela Larvae (Coleoptera: Scarabaeidae). PLoS One, v. 8, n. 2, e57169. https://doi.org/10.1371/journal.pone.0057169

HYPOLITO, R.; EZAKI, S. (2006) ĺons de metais pesados em sistema solo-lixo-chorume-água de aterros sanitários da região metropolitana de São Paulo-SP. Águas Subterrâneas, São Paulo, v. 20, n. 1, p. 99-114. https://doi.org/10.14295/ras.v20i1.9716

JAIN, P.; KIM, H.; TOWNSEND, T.G. (2005) Heavy metal content in soil reclaimed from a municipal solid waste landfill. Waste Management, v. 25, n. 1, p. 25-35. https://doi.org/10.1016/j.wasman.2004.08.009

KENNEDY, A.C. (1999) Bacterial diversity in a groecosystems. Agriculture, Ecosystems \& Environment, v. 74, n. 1-3, p. 65-76. https:// doi.org/10.1016/S0167-8809(99)00030-4

KEYSER, M.; WITTHUHN, R.C.; LAMPRECHT, C.; COETZEE, M.P.A.; BRITZ, T.J. (2006) PCR-based DGGE fingerprinting and identification of methanogens detected in three different types of UASB granules. Systematic and Applied Microbiology, v. 29, n. 1, p. 77-84. https://doi.org/10.1016/j.syapm.2005.06.003

KLOCKE, M.; MÄHNERT, P.; MUNDT, K.; SOUIDI, K.; LINKE, B. (2007) Microbial community analysis of a biogas-producing completely stirred tank reactor fed continuously with fodder beet silage as mono-substrate. Systematic and Applied Microbiology, v. 30, n. 2 , p. 139-151. https://doi.org/10.1016/j.syapm.2006.03.007

KORF, E.P.; MELO, E.F.R.Q.; THOMÉ, A.; ESCOSTEGUY, P.A.V. (2008) Retenção de metais em solo da antiga área de disposição de resíduos sólidos urbanos de Passo Fundo - RS. Revista de Ciências Ambientais, Canoas, v. 2, n. 2, p. 43-60. http://doi.org/10.18316/119

LALUCAT, J.; BENNASAR, A.; BOSCH, R.; GARCIA-VALDÉS, E.; PALLERONI, N.J. (2006) Biology of Pseudomonas stutzeri. Microbiology and Molecular Biology Reviews, v. 70, n. 2, p. 510-547. https://doi.org/10.1128/MMBR.00047-05

LIU, P.; JI, J.; WU, Q.; REN, J.; WU, G.; YU, Z.; XIONG, J.; TIAN, F.; ZAFAR, Y.; LI, X. (2018) Klebsiella pneumoniae sp. LZU1O degrades oil in food waste and enhances methane production from co- digestion of food waste and straw. International Biodeterioration \& Biodegradation, v. 126, p. 28-36.

MATA-ALVAREZ, J. (2002) Biomethanization of the organic fraction of municipal solid waste. 2. ed. Londres: Iwa Publishing. 323 p.

MELO, M.C. (2003) Uma análise de recalques associada à biodegradação no aterro de resíduos sólidos da Muribeca. 141f. Dissertação (Mestrado em Ciência em Engenharia Civil) Centro de Tecnologia e Geociências, Universidade Federal de Pernambuco, Recife.

MONTEIRO, V.E.D. (2003) Análises físicas, químicas e biológicas no estudo do comportamento do Aterro da Muribeca. 246f. Tese (Doutorado em Engenharia Civil) - Universidade Federal de Pernambuco, Recife.

MUYZER, G.; WALL, E.C.; UITTERLINDEN, A.G. (1993) Profiling of complex microbial populations by denaturing gradient gel electrophoresis analysis of polymerase chain reaction amplified genes coding for 165 rRNA. Applied and Environmental Microbiology, v. 59, n. 3, p. 695-700.

ODEYEMI, A.T.; ADERIYE, B.I.; BAMIDELE, O.S. (2013) Lipolytic Activity of some Strains of Klebsiella, Pseudomonas and Staphylococcus Spp. from Restaurant Wastewater and Receiving Stream. Journal of Microbiology Research, v. 3, p. 43-52.

OLIVEIRA, J.S.; JUCÁ, J.F. (2004) Acúmulo de metais pesados e capacidade de impermeabilização do solo abaixo de uma célula de um aterro de resíduos sólidos. Engenharia Sanitária e Ambiental, v. 9 , n. 3, p. 211-217. https://doi.org/10.1590/S1413-41522004000300007

PATEL, V:; MUNOT, H.; SHOUCHE, Y.S.; MADAMWAR, D. (2014) Response of bacterial community structure to seasonal fluctuation and anthropogenic pollution on coastal water of Alang-Sosiya ship breaking yard, Bhavnagar, India. Bioresource Technology, v. 161, p. 362-370. https://doi.org/10.1016/j.biortech.2014.03.033

QUINTAES, B.R.; CAMPOS, J.C:; MIGUEL, M.A.L.; LEITE, A.M.O.; HINOJOSA, M.A.G. (2014) Uso de Ferramentas Moleculares para Estudos de Comunidades Microbianas em Lixiviado de Aterro de Resíduos Sólidos Urbanos. Revista Brasileira de Ciências Ambientais, n. 31, p. 30-43.

RODRÍGUEZ, H.; FRAGA, R. (1999) Phosphate solubilizing bacteria and their role in plant growth promotion. Biotechnology Advances, v. 17, n. 4-5, p. 319-339. https://doi.org/10.1016/S0734-9750(99)00014-2

SAMBROOK, J.; RUSSEL, D.W. (2001) Molecular cloning: a laboratory manual. 3. ed. Nova York: Cold Spring Habour Laboratory Press.

SANTOS, A.L. (2010) Diversidade molecular microbiana de lixiviados de aterros. 100f. Tese (Doutorado em Ciências - Microbiologia) - Instituto de Microbiologia Prof. Paulo de Góes, Universidade Federal do Rio de Janeiro, Rio de Janeiro.

SANTOS, A.L.; PEIXOTO, R.; ROSADO, A.S. (2009) New approaches to understanding microbial diversity in wastewater, landfills and leachate treatment. Oecologia Brasiliensis, v. 13, n. 4, p. 631-648. https://doi.org/10.4257/oeco.2009.1304.07 
SAWAMURA, H.; YAMADA, M.; ENDO, K.; SODA, S.; ISHIGAKI, T.; IKE, M. (2010) Characterization of microorganisms at different landfill depths using carbon-utilization patterns and 16S rRNA gene based T-RFLP. Journal of Bioscience and Bioengineering, v. 109, n. 2 , p. 130-137. https://doi.org/10.1016/j.jbiosc.2009.07.020

SILVA, A. dos S. (2016) Análise de componentes tóxicos em resíduos sólidos urbanos. 158f. Tese (Doutorado em Ciência e Engenharia de Materiais) - Universidade Federal de Campina Grande, Campina Grande.

SISINNO, C.L.S.; MOREIRA, J.C. (1996) Avaliação da contaminação e poluição ambiental na área de influência do aterro controlado do Morro do Céu, Niterói, Brasil. Cadernos de Saúde Pública, Rio de Janeiro, v. 12, n. 4, p. 515-523. https://doi.org/10.1590/S0102311X1996000400010

SOLLÉRO, B.P.; FARIA, D.A.; PAIVA, S.R.; GUIMARÃES, S.E.F.; LOPES, P.S.; PAIXÃO, D.M. (2004) Método rápido de extração de DNA utilizando CTAB em tecidos musculares de suínos. In: CONGRESSO NACIONAL DE ZOOTECNIA. Anais... Brasília: Associação Brasileira de Zootecnistas. p. 1-4.

SONG, L.; WANG.; TANG, W.; LEI, Y. (2015) Bacterial community diversity in municipal waste landfill sites. Applied Microbiology and Biotechnology, v. 99, n. 18, p. 7745-7756. https://doi.org/10.1007/ s00253-015-6633-y

SUN, H.Y.; CHEN, S.Y; CHANG, S.C.; PAN, S.C.;SU, C.P.; CHEN, Y.C.(2OO6) Community - onset Escherichia coli and Klebsiella pneumoniae bacteremia: influence of health care exposure on antimicrobial susceptibility. Diagnostic Microbiology and Infectious Disease, v. 55, n. 2, p. 135-141. https://doi.org/10.1016/j.diagmicrobio.2006.01.004

SZYŁAK-SZYDŁOWSKI, M.; KORNIŁŁOWICZ-KOWALSKA, T. (2O12) The mycobiota of landfill leachates in the pretreatment process in a sequencing batch reactor. Central European Journal of Biology, v. 7. p. 250-258. https://doi.org/10.2478/s11535-012-0010-y

TAKAYANAGUI, O.M.; CAPUANO, D.M.; OLIVEIRA, C.A.D.; BERGAMINI, A.M.M.; OKINO, M.H.T.; SILVA, A.A.M.C.C.; OLIVEIRA, M.A.; RIBEIRO, E.G.A.; TAKAYANAGUI, A.M.M. (2007) Avaliação da contaminação de hortas produtoras de verduras após a implantação do sistema de fiscalização em Ribeirão Preto, SP. Revista da Sociedade Brasileira de Medicina Tropical, v. 40, n. 2, p. 239-241. https://doi. org/10.1590/S0037-86822007000200020

TOMASSONI, F; SANTOS, R.F;; SANTOS, F.S.; CARPINSKI, M.; SILVEIRA, L. (2014) Técnica de biorremediação do solo. Acta Iguazu, Cascavel, v. 3, n. 3, p. 46-56

WATANABE, T; ASAKAWA, S.; NAKAMURA, A.; NAGAOKA, K.; KIMURA, M. (2004) DGGE method for analyzing 16S rDNA of methanogenic archaeal community in paddy field soil. FEMS Microbiology Letters, v. 232, n. 2. p. 153-163. https://doi.org/10.1016/ SO378-1097(O4)00045-X

XIAOLI, C.; SHIMAOKA, T; XIANYAN, C.; QIANG, G.; YOUCAI, Z. (2007) Characteristics and mobility of heavy metals in an MSW landfill: implications in risk assessment and reclamation. Journal Hazard Materials, v. 144, n.1-2, p. 485-491. https://doi.org/10.1016/j. jhazmat.2006.10.056

XIE, J.; HE, Z;; LIU, X.; LIU, X.; VAN NOSTRAND, J.D; DENG, Y.E.; WU, L.; ZHOU, J.; QIU, G. (2011) GeoChip-Based Analysis of the Functional Gene Diversity and Metabolic Potential of Microbial Communities in Acid Mine Drainage. Applied and Environmental Microbiology, v. 77, n. 3, p. 991-999. https://doi.org/10.1128/AEM.01798-10

XIE, B.; XIONG, S.; LIANG, S.; HU, C:; ZHANG, X.; LU, J. (2012) Performance and bacterial compositions of aged refuse reactors treating mature landfill leachate. Bioresource Technology, v. 103, n. 1, p. 71-77. https://doi.org/10.1016/j.biortech.2011.09.114

ZHANG, D.; KEAT, T.S.; GERSBERG, R.M. (2010) A comparison of municipal solid waste management in Berlin and Singapore. Waste Management, v. 30, n. 5, p. 921-933. https://doi.org/10.1016/j. wasman.2009.11.017

ZHENG, J.; CHEN, K.H.; YAN, X.; CHEN, S.J;; HU, G.C.; PENG, X.W.; YUAN, J.G.; MAI, B.X.; YANG, Z.Y. (2013) Heavy metals in food, house dust, and water from an e-waste recycling area in South China and the potential risk to human health. Ecotoxicology and Environmental Safety, v. 96, p. 205-212. https://doi.org/10.1016/j.ecoenv.2013.06.017 